\title{
RELATIONSHIP BETWEEN ONLINE SOCIAL NETWORKING SITES \& APPLICATIONS AND UNIVERSITY STUDENTS' ACHIEVEMENT
}

\section{Syed Zubair Haider ${ }^{1 *}$, Uzma Munawar ${ }^{2}$, Hamida Bibi ${ }^{3}$, Farooq Hussain ${ }^{4}$, Abdul Wadood ${ }^{5}$}

${ }^{1 *}$ Assistant Professor, Department of Educational Training, The Islamia University of Bahawalpur, Pakistan; ${ }^{2}$ Assistant Professor, Department of Education, Govt Sadiq College Women University, Bahawalpur, Pakistan; ${ }^{3}$ Lecturer Bacha Khan Medical College Mardan. Khyber Pakhtunkhwa, Pakistan; ${ }^{4}$ Assistant Professor, Abdul Wali Khan University, Mardan, Khyber Pakhtunkhwa, Pakistan; ${ }^{5}$ Assistant Professor, Department of Education, Sarhad University of Science and Information Technology Peshawar, Khyber Pakhtunkhwa, Pakistan.

Email: ${ }^{1 *}$ zubairiub@ @otmail.com, ${ }^{2}$ druzmamunawar@ gmail.com, ${ }^{3}$ tazkiasayed@ gmail.com,

${ }^{4}$ farooqhussain@awkum.edu.pk, ${ }^{5}$ abdul.wadood3376@gmail.com

Article History: Received on $21^{\text {st }}$ May 2021, Revised on $14^{\text {th }}$ June 2021, Published on $29^{\text {th }}$ June 2021

\begin{abstract}
Purpose of the study: This study analysed the relationship between Online Social Networking websites and Applications (OSNSA) and university students' academic achievement.
\end{abstract}

Methodology: In the present research, a quantitative research design was followed, and a survey research type of descriptive research was used in this study. Data were collected from 150 university students using a modified version of The Online Social Networking Sites scale (Paul, Baker, \& Cochran, 2012). The correlation was calculated by using the SPSS $22^{\text {nd }}$ version.

Main Findings: The findings revealed a connection between students' time spent on OSNSA and their academic outcomes. The time spent on OSNSA was observed to be strongly influenced by the attention span of the students. In particular, we find that a lower academic output is provided by the greater time spent on OSNSA. Also, attention span was strongly associated with features that influence students' academic success, such as their perceptions of society's social networking outlook, their advantages, and disadvantages of OSNSA, use of OSNSA, etc.

Applications of this study: Many students spend most of their hours on online networking pages, like Facebook, TokTok, and WhatsApp, which are the most common, considering the harmful impact of social media. In certain eyes, social media has embedded a detrimental effect, but it is also used to acquire vital knowledge and social skills for pupils.

Novelty/Originality of this study: This research is different from other studies because it explores the relationship between social networking sites \& the application and academic performance of university students belonging from South Punjab by exploring various facets of OSNSA which ultimately promote university students' academic performance.

Keywords: Online Social Networking, Facebook, Twitter, Students'Achievement.

\section{INTRODUCTION}

The invention of the Internet in the 1990s led to significant changes in the communication world, thus the emergence of online social networking websites and applications (OSNSA). The OSNSA is used daily by several millions of users, such as Facebook, Twitter, WhatsApp, Tik-Tok, Myspace, etc. University students make up a large proportion of this online networking culture. Through the Internet, people make new friends to communicate with other people, whether for the company or commercial purposes. As part of their routine, many students often log in to their Facebook account, Twitter, etc. Every day, millions of students $\log$ on to these social networking sites. That's why many students have blamed their steady decline in grade point averages on different social networking sites. This new phenomenon inspired us to see at OSNSA and why they impact the academic success of fellow students (Gierdowski, 2019).

OSNSA can be used in education to exchange knowledge with students, collect data while studying abroad or when doing studies, share personal academic interests with others, hold students and recognize what they think while teaching, and enhance casebook functions by connecting students to interactive resources (Obi, Bulus, Adamu, \& Sala'at, 2012). The OSNSA also develops the capacity of students to build their delight in academic subjects, and through OSNSA, students interact more effectively with operating teachers. Cox and McLeod (2014) found that OSNSA facilitates contact between teachers, students, parents, and community members and helps to build professional online learning societies that influence students' academic achievements.

Millions of people actively use OSNSA, such as Facebook, Twitter, Instagram, WhatsApp, Tik-Tok, and Myspace. College and university students make up a large proportion of this online networking culture (Dahlstrom, Grunwald, de Boor, \& Vockley, 2011). Given OSNSA's success, several institutions use it to sell programs and engage with present and potential students and alumni. Some instructors are beginning to utilize OSNSA to favourably affect class discussions and project collaborations and improve learning outcomes through enhanced communication with and among students in their classrooms. However, a recent study suggests that student over-involvement or fascination with social networking can have detrimental effects on academic success (Busalim, Masrom, \& Zakaria, 2019). So, the effect 
of social media has sparked discussion among academics from many disciplines and universities on the usefulness and viability of OSNSA as a teaching tool.

Concerning OSNSA, several other variables affect the achievement of the students in conjunction or separately. In the present research, the effect of the following five variables such as time spent, attention span, academic competence, prediction activity, and time management are examined. The time spent is a period between two events or during which something occurs. We cannot picture a time as long as a million years in our minds (Laranjo et al., 2015). Attention span is described as the length of time during which one can focus or remain interested (such as a person or a group) or the length of time during which someone can think about or remain interested in something. We specified the portion of the attention span, as discussed earlier, to prevent misunderstanding as an attention disorder. The essential connection between time spent on OSNSA and an attention deficit. Higher ranks of the attention deficit have contributed to a higher amount of time spent on OSNSA. When compared to that reported in Greenfield, the direction of this relationship provides further evidence of the existence of a pure connection among these variables. No pure connection between the time spent on OSNSA and Variables with other school attributes was identified.

Through their attempts to enhance their teaching efforts and assist in the learning process of their pupils, academic excellence is a framework used in the education department (Onurkan Aliusta \& Özer, 2017). The connection between academic competence and academic success is positive but indirect. We see that academic competence correlates favourably with the principles of time management and student attributes, all of which positively affect academic success. The indirect relationship is also important. Initially, we predicted a strong correlation between academic competence and academic achievement. More precisely, there is a negative link between academic competence and attention deficits, hurting the students' achievement.

The connection between (OSNSA) behaviour predictors and the performance of students is not as clear. The behaviour construct predictors are negatively associated with both attention deficit and time management, which have opposite effects on academic performance. Therefore, we cannot assume that academic success is substantially affected by student behaviour predictors. The process of organizing and planning how to divide your time between particular activities is time management (Grønmo, 2019). The new notion of time management, the act of planning the amount of time you spent on the tasks introduced by Frederick Taylor's scientific management techniques. As the time management score rises, academic performance improves, suggesting that successful time management contributes to enhanced academic performance. That is why, as stated by Razali, Rusiman, Gan, and Arbin (2018), the connection between time management and academic performance links together.

Skills in time management, student features, and time spent on OSNSA greatly affect academic results. The only direct correlation found with time spent on OSNSA was with the structure of the attention deficit. The amount of time spent on OSNSA grows as the extent of the attention deficit increases (Gupta \& Chitkara, 2018). Other non-directional connections between the leading constructs to correlations between such constructs and academic performance and time spent on OSNSA, either implied or indirect. Academic competence, for instance, is positively linked to the characteristics of students and time management, which suggests an indirect correlation between academic competence and academic success. The attention deficit has a substantial positive effect on the time spent on OSNSA, which has a negative impact on academic performance, thus suggesting an indirect correlation between the attention deficit and academic performance. Anticipated behaviour, as mentioned earlier, is significantly linked to time management and attention deficit, but not to the main interest, academic performance, and time spent on OSNSA constructs. Because of the observed relationships, it would be worthwhile to investigate further the planned actions construct study (Klimova, 2019).

\section{STATEMENT OF THE PROBLEM}

The characteristics of respondents are, first and foremost, considered an important field of social science. Literature about places for networking. It will help us define their life duration, sex, faith, marital status, and level of education. To categorize and measure their time spent online. Like many aspects of their lives, today's university students are introduced to all types of technology (Kumar Behera, 2021). They make frequent use of computers, printers, laptops, and cell. Social networking, text, story writing, sharing of information, online studying, and other activities are engaged (Tayo, Adebola, \& Yahya, 2019). Today, the Internet is the most astounding source of information, and the growing importance of students' usage of social media cannot be overstated. Students have been found to give more importance and time to social sites than their studies, and they do not pass their examinations well if they do not study. Students today are involved at all levels in the use of OSNSA, especially at the tertiary level. Therefore, this study aims to explore the level of university students' engagement in OSNSA and assess the impact of their use on academic work.

\section{LITERATURE REVIEW}

\section{CONCEPT OF ONLINE SOCIAL NETWORKING SITES AND APPLICATIONS}

The study focuses on the influence of social networks (Twitter, WhatsApp, Facebook, etc.) on learners' academic performance. Social media continues to evolve, and, as such, it is impossible to give a set meaning that social media does not have a single proper definition. However, some observers have described it in many different ways. Students 
and adolescents have been drawn to social sites. Social sites are also defined as websites and applications used for social networking (Nicholson, 2018). Another concept of social sites is that it is an online forum for users to build a public profile and connect with other users (Abrha, 2019). Some of these meanings show the relation between people via the Internet.

Students and adolescents who have been labelled 'Digital Natives are the main consumers of social networks. Digital Natives refer to those born during the digital technology era. Students in higher education are the most frequent users. The most useful websites and their friends and teachers are in touch. Some learners take more time to share their thoughts, imagination, jobs, and tasks with their peers on social media in a positive way (Abdullahi, Musa, \& Yusif, 2020). They use social media for research purposes, and social media websites support their analysis and academic success. Social networking has strengthened communication skills between their peers and members of their faculty. We develop their writing and reading skills and enhance their style of learning. Social media helps students cultivate their thoughts and ideas to enhance their knowledge (Talaue, AlSaad, AlRushaidan, AlHugail, \& AlFahhad, 2018).

Teenagers and adults are connected to their peers, exchanging knowledge and imagination through the expanded use of social networking sites. The improved technology used to communicate with others and social networks have become an operation like Facebook carried out on the Internet. Students communicate with others, share knowledge about their desires, debate on social networks about particular topics. For their everyday activities and knowledge collection, teens use the Internet to use television or newspapers like the old generation. Moreover, 15.4 million users use Facebook, representing 8.5 million people in the overall population, according to the 2015 report. Among students, social media websites have become increasingly popular. In examinations that are more based on social media, Facebook users perform poorly (Asha, 2017).

Platforms for social sites have a large impact on student's performance. Academic success is described as how students manage their studies and how their teachers perform various tasks. This indicates that friendship also allows direct and indirect access to information and knowledge essential. The activities of a student, such as making new friends, exchanging information, awareness, sharing ideas, thoughts, and enhancing their social media network. Facebook users also encounter bad academic achievement (Talaue et al., 2018). Academic success was also defined as how the student retained his or her career. Several variables influence the actions and success of students in terms of how often students use social media, whether they use social media more and do not display interest in academic performance. Academic success is also described as the degree to which the short or long-term educational objectives of a student, teacher, or institution have been achieved.

\section{POSITIVE EFFECTS OF OSNSA ON STUDENTS' ACHIEVEMENTS}

Social sites have both positive and adverse impacts on the academic success of students. Yet, there is a debate about the positive impact of social sites. Social sites allow students to exchange data, information, and tasks with their fellow students and teachers. Via an online dictionary and online English courses, they develop their vocabulary. They even learn things about their tasks and quickly make their assignments. They communicate with their peers and teachers and quickly solve their issues.

\section{Mental Health}

Mental health can benefit from social media. They change their mood, as though someone is in a poor mood, and they use social media and watch funny videos and poetry, etc. By stretching their scope, social media will help therapists and psychiatrists. Mental health professionals commonly use social networking sites such as Tik-Tok, Tumblr, and Pinterest to collect data for study and interact with other online world experts (de Calheiros Velozo \& Stauder, 2018). For people with disabilities, such as older people and people with physical disabilities, it may also help sustain relationships that impair their mobility and discourage travel outside the home. Social networking may offer new ways of seeking encouragement, even helping to eliminate depression, far from growing loneliness.

\section{Enhance Talent}

Social media also develops students' skills, and they understand more things. This creates confidence and self-esteem and effective in reducing depression. It offers the possibility of learning online for any student and makes it simple to have immediate access to reliable information. Instead of travelling to the library, you may save time and get the information you need by utilizing Google. Online services are also highly useful if the data is not available at the library (Emanuela, 2018). On the Internet, you may get sample papers as well as useful hints on how to complete entire tasks effectively. Serves as an important academic success system. For collaboration, social media networks can be efficiently used. For instance, it is easier to meet online and discuss the assignment together if you are assigned to study a certain topic together with a group.

\section{Improve Communication}

Social networking can enhance people's contact. They communicate with one another as they interact with other friends. This is the reason many individuals have invested a fair amount of time on social media. Our time is being spread thinner and thinner by obligations to work and family. However, social networking sites provide an opportunity to 
communicate quickly and efficiently, especially when everyone involved is involved. Han and Xu (2020) express that it can carry a significant amount of traffic to a website if any social media platform is right. It also informs you about brand recognition and loyalty to the brand.

\section{NEGATIVE EFFECTS OF OSNSA ON STUDENTS' ACHIEVEMENTS}

There is a negative link between social media and the academic success of students, which is far stronger than the gains obtained by using social sites. People worldwide have been hooked to the Internet, causing more students to more actively using networking sites than ever before. There are more time students spent on social media. They are more addicted to Facebook and Tik-Tok nowadays. Some of the social sites that have negative effects are:

\section{Stress and Depression}

It can result in poor sleep by giving a lot of time on social sites, the biggest negative influence on people's increased risk of anxiety and depression. It provides an unhealthy pattern of sleep. Students may be affected by laptops, cell phones, and other devices to access online services if they use them regularly for long hours. Students can be subjected to poor posture, eye pressure, mental and physical stress (Bettmann, Anstadt, Casselman, \& Ganesh, 2020). Too many educational technology resources by students to access social media is detrimental, and there must be a cap. Both stakeholders in education must ensure that they manage social media channels by developing a strategy that will help monitor the negative impact of social media. Students must also be prepared in class to learn and listen. They should not make their priority talking. Students should seek exemplary academic achievement and develop sufficient information that will assist them in the future.

\section{Privacy}

Privacy, also in the social media world, remains one of the most important things for individuals. However, keeping up with the pace can be very hard (Connelly \& Osborne, 2017). Massive data are collected and stored in databases by administration departments, search appliances, online systems, hospitals, economic corporations, and other communities. With this data, individuals will use it for detrimental purposes and harm the life of one person. Still, if individuals pursue and decide the privacy and protection choices, they may be less protected (Di Minin, Fink, Hausmann, Kremer, \& Kulkarni, 2021). For people, the gathered data is very important, and people might mishandle this data. These days, so much is posted online that privacy concerns are becoming an increasingly significant concern. If it's a case of social websites owning the material after it's posted, becoming a victim after uploading your geographical position online, or simply getting into trouble at work after tweeting so often of something inappropriate to communicate with the public will open up all manner of problems that can sometimes never be reversed.

\section{Addictive}

Social media, even more so than smoking and alcohol, can be rather addictive. People are more used to these sites (Celestine \& Nonyelum, 2018) as a drug. Social sites are often described as more destructive than tobacco and alcohol, with the worst social networking apps regarding addiction being WhatsApp, Telegram, Twitter, and Tik-Tok. If you just discovered that you are a social media user, do not worry, as most of us are with you to varying degrees. And it's not a justification for all those social networking sites to go and wash you off (Schroeder, Minocha, \& Schneider, 2010). Research from the University of Pittsburgh shows that for adults between the ages of 19-32, the use of social networking sites causes a substantial rise in depression and depression-like symptoms. These platforms' addictive characteristics may contribute to enhancing or increasing narcissistic behaviours and personality characteristics. It may contribute to behaviours of hyperactivity, resistance to figures of authority, and even general inattention.

\section{Time Wastage}

When browsing and studying online, students become addicted to utilizing social media platforms, and they frequently forget why they use the Internet. This wastes their time, and students are frequently unable to complete their assignments within the allotted time. During class, students use the Internet to spend time before the teacher arrives. Owing to a lack of knowledge about the subject, students get a low grade in the class. Students mostly use slang phrases and shorten the shape of phrases during school, and these phrases are often used in class and on paper (Indurthi, Syed, Gupta, \& Varma, 2020). Tik-Tok is a big website that influences students' academic performance as they use Tik-Tok more on the Internet. Owing to the disproportionate amount of time they spend on online communities, their association with unreal peers, and reduced academic results, social networks have a lot of negative impacts on the academic life of university students.

The main hypothesis of the study was

H1: There will be a significant relationship between time-span and students' academic achievement.

H2: There will be a significant relationship between time management and students' academic achievement.

H3: There will be a significant relationship between attention span and students' academic achievement.

H4: There will be a significant relationship between academic competency and students' academic achievement. 
H5: There will be a significant relationship between prediction behavior and students' academic achievement.

\section{METHODOLOGY}

A quantitative research design was followed in this study, and a survey research type of descriptive research was used in this study. A sample of 150 students was conveniently selected from different departments of The Islamia University of Bahawalpur. Data were obtained using the questionnaire provided online to the students. Due to the COVID-19 Pandemic situation, the university was closed, and face-to-face data collection was impossible due to strict lock-down. Due to the strong follow-up of questionnaires, we received filled questionnaires within one week from their distribution time. However, when they were thoroughly scrutinized, 145 questionnaires were found properly filled and complete in all aspects used in this study. The Online Social Networking Sites scale developed by (Paul, Baker, \& Cochran, 2012) was modified and used in this study after getting permission from authors. The scale is based on five sub-scales such as time spent on OSNSA (03 items), time management (06 items), attention span (03 items), academic competency (04 items), and behaviour prediction (12 items). For this study, the overall internal reliability of the scale was 0.91 . We use the SPSS version $22^{\text {nd }}$ for data analysis and frequency, percentage, independent sample t-test, and Pearson correlation analysis were computed to strengthen the determination and conclusions.

\section{RESULTS/FINDINGS}

Table 1: Demographics of Respondents

\begin{tabular}{llll}
\hline & Characteristics & Frequency & Percent \\
\hline Gender & Male & 31 & 21.3 \\
\hline & Female & 114 & 78.6 \\
\hline Marital Status & Married & 24 & 16.5 \\
\hline & Un-Married & 121 & 83.4 \\
\hline Origin & Urban & 100 & 68.9 \\
\hline Qualification & Rural & 45 & 31.0 \\
\hline & Bachelor & 60 & 41.37 \\
\hline & Master & 55 & 37.9 \\
\hline & M.Phil. & 22 & 15.1 \\
\hline & Ph.D. & 8 & 5.5 \\
\hline
\end{tabular}

This table is the sum of the respondents' details. The status shows that $78.6 \%$ of students were female, and $21.3 \%$ were male. Therefore, the bulk of students were women in the study. Also, 83.4\% of students were un-married, and $16.5 \%$ were married. Therefore, in the sample, the majority of students were un-married. Moreover, $68.9 \%$ of students were from the urban area, and $31 \%$ were from rural areas. Therefore, in the sample, the majority of students belong to urban localities. Moreover, $41.37 \%$ of students were Bachelor's degree holders, $37.9 \%$ were Master, $15.1 \%$ were M.Phil, and $5.5 \%$ were Ph.D. degree holders. Therefore, in the sample, the majority of students were from bachelor classes.

Table 2: Gender-wise comparison of Time-Span

\begin{tabular}{llllll}
\hline Gender & $\mathbf{N}$ & Mean & SD & t & Sig \\
\cline { 1 - 4 } Male & 31 & 3.0133 & 1.00222 & 1.053 & .029 \\
\cline { 1 - 4 } Female & 114 & 2.8442 & .64317 & & \\
\hline
\end{tabular}

The results in Table 2 show that there is a significant difference between the mean male score $(M=3.01, S D=1.00)$ and the female respondents $(M=2.84, S D=.643)$. The Sig value is less than .05 , which indicates that the difference is significant, and the perceptions of both male and female students on time-span $t(144)=1.05$, Sig $=.029$ are almost unequal.

Table 3: Gender-wise comparison of Time Management

\begin{tabular}{llllll}
\hline Gender & $\mathbf{N}$ & Mean & SD & t & Sig \\
\cline { 1 - 4 } Male & 31 & 3.0600 & .51792 & .273 & .785 \\
\cline { 1 - 5 } Female & 114 & 3.0249 & .59028 & & \\
\hline
\end{tabular}

The results in Table 3 show that there is no significant difference between the mean score of males $(M=3.06, S D=$ $.517)$ and female respondents $(M=3.02, S D=.590)$. The Sig value is greater than .05 , indicating that the difference is not significant and both genders have almost the same views regarding Time Management $t(144)=.273$, Sig $=.785$.

Table 4: Gender-wise comparison of Attention Span

\begin{tabular}{llllll}
\hline Gender & $\mathbf{N}$ & Mean & SD & t & Sig \\
\cline { 1 - 5 } Male & 31 & 2.9100 & .74260 & .320 & .750 \\
\cline { 1 - 5 } Female & 114 & 2.8598 & .69802 & & \\
\hline
\end{tabular}


The result in Table 4 reveals that there is no significant difference between the mean score of males $(M=2.91, S D=$ $.742)$ and female $(M=2.85, S D=.698)$ students. The Sig value is greater than .05 , which shows that the difference is not significant, and both male and female students have almost the same opinions regarding Attention Span $t(144)=.320$, Sig $=.750$.

Table 5: Gender-wise comparison of Academic Competency

\begin{tabular}{llllll}
\hline Gender & $\mathbf{N}$ & Mean & SD & t & Sig \\
\cline { 1 - 4 } Male & 31 & 3.9760 & .60366 & 1.854 & .046 \\
\cline { 1 - 5 } Female & 114 & 3.6729 & .76251 & & \\
\hline
\end{tabular}

The results in Table 5 show that there is a significant difference between the mean score of males $(M=3.97, S D=.603)$ and female $(M=3.67, S D=.762)$ respondents. The Sig value is smaller than .05 , which shows that the difference is significant, and both male and female students have almost different opinions regarding Academic Competency $t(144)=$ 1.85, Sig $=.046$.

Table 6: Gender-wise comparison of Prediction Behavior

\begin{tabular}{llllll}
\hline Gender & $\mathbf{N}$ & Mean & SD & t & Sig \\
\hline Male & 31 & 3.7067 & .58636 & .571 & .569 \\
\cline { 1 - 4 } Female & 114 & 3.6199 & .70415 & & \\
\hline
\end{tabular}

The result in Table 6 reveals that there is no significant difference between the mean score of males $(M=3.70, S D=$ $.586)$ and female $(M=3.61, S D=.706)$ students. The Sig value is greater than .05 , which shows that the difference is not significant, and both male and female students have almost the same opinions regarding Prediction Behaviour $t(144)=$ .571, Sig $=.569$.

Table 7: Pearson Correlation Matrix

\begin{tabular}{lllllll}
\hline & $\mathbf{1}$ & $\mathbf{2}$ & $\mathbf{3}$ & $\mathbf{4}$ & $\mathbf{5}$ & $\mathbf{6}$ \\
\hline 1. Time Span & 1 & & & & & \\
\hline 2. Time Management & .140 & 1 & & & & \\
\hline 3. Attention Span & $.225^{* *}$ & $.332^{* *}$ & 1 & & & \\
\hline 4. Academic Competency & -.008 & $.463^{* *}$ & $.309^{* *}$ & 1 & & \\
\hline 5. Prediction Behaviour & .050 & $.347^{* *}$ & $.239^{* *}$ & $.621^{* *}$ & 1 & \\
\hline 6. Overall GPA & -.077 & .022 & .055 & .018 & $-.216^{*}$ & 1 \\
\hline
\end{tabular}

*. Correlation is significant at .05

**. Correlation is significant at .01

The connection between research variables and the success of the students as seen in Table 7. Time management has a poor positive correlation with attention $\operatorname{span}(r=.225, p<.01)$. Time management has a moderate positive correlation with attention $\operatorname{span}(r=.332, p<.01)$, a moderate positive correlation with academic competence $(r=.463, p<.01)$ and a moderate positive correlation with prediction behavior $(r=.347, p<.01)$. There is a moderate positive association between attention span and academic competence $(r=.309, p<.01)$ and a small positive correlation between predictive behavior $(r=.239, p<.01)$. There is a moderate positive association between academic competence and prediction behaviour $(r=.621, p<.01)$. There is a weak negative correlation between predictive behaviour and total GPA $(r=-$ $.216, p<.05)$.

\section{DISCUSSION/ANALYSIS}

Education is enthusiastic about experimenting with new or enhanced technology to improve education and learning. Social media has evolved as a very effective instrument for personal communication (Tess, 2013). Social media is a rapidly growing interactive learning technology in higher education, with an unmatched ability to facilitate communication and link students and professors in a virtual community. (Sobaih, Moustafa, Ghandforoush, \& Khan, 2016). This study investigates the relationship of OSNSA in higher education with particular references to students' academic achievement. We answer the questions raised earlier in the paper using the outcomes presented. Is there any relationship between time-span and students' academic achievement? There is a negative relationship between time-span and students' academic achievement. The same results were presented by David, Helou, and Rahim (2012) that social media is a new interactive learning technology for higher education that has a clear communications advantage and unites students and teachers in a virtual community. Timespan has a negative effect on students' academic achievement. When the time span increases, then the achievement of students decreases and affects students' academic achievement.

Students' academic performance and achievements are greatly aided by effective time management. Every student should be able to manage their time well, which involves defining objectives and priorities, utilizing time management mechanisms, and being structured in their use of time (Nasrullah \& Khan, 2015). The present study obtained the same result, there is a positive relationship between time management and people's connections and students' academic 
achievement. When we manage the time then they will not decrease the result of students' academic achievement. As a result of this reality, time management concerns have received special attention in the current educational system, with students' attitudes and actions linked to time and its management being evaluated (Karim \& Kandy, 2011).

Attention span is the length of time during which a person can concentrate on a subject or idea. There is no significant relationship between attention span and students' academic achievement. Increased attention span has resulted in a negative impact on student's academic achievement. The results of Jena (2019) also indicated an inverse relationship between one's attention span and performance, a rise in arousal causes attention to constrict, whereas a fall in arousal causes attention to expanding. A student's attention span is an important component in learning; if the learner is continually reminded to listen or pay attention, learning will be impeded, and time will be lost (Cicekci \& Sadik, 2019). Furthermore, With the freedom of access to the internet, it affects the students' academic achievement and increases the risk towards the attention span of students (Rodríguez Longarela, 2020). Moreover, the other question was to indicate the relationship between academic competency and students' academic achievement? There is a positive relationship between academic competency and students' academic achievement. There is a positive relationship between academic competency and time management because they positively affect students' academic achievement. A negative relationship between attention span and prediction behavior because they affect students' academic achievement. Is there any relationship between prediction behaviour and students' academic achievement? There is no clear relationship between prediction behaviour and students' academic achievement because they negatively correlate with attention span and academic competency and a positive relationship with time-span.

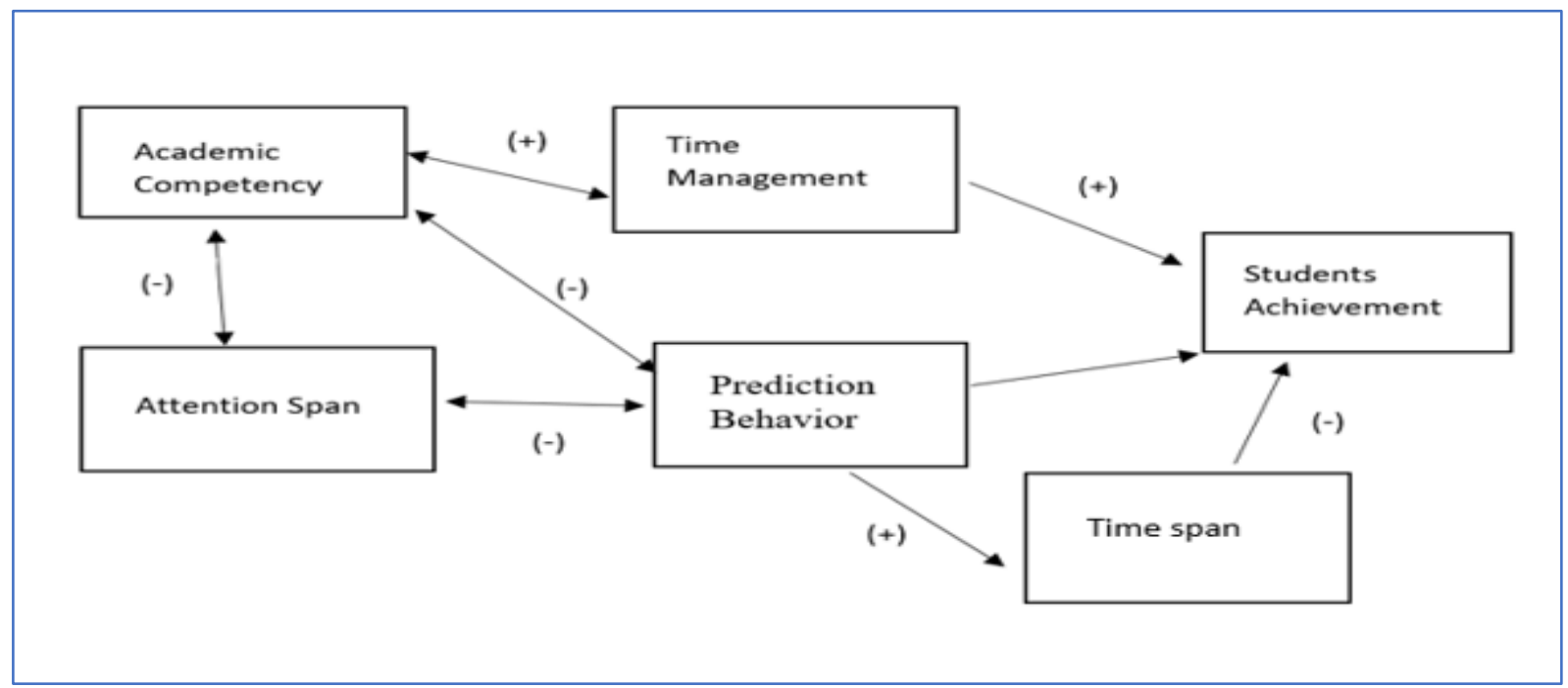

Figure 1: Final Model representing the Effect of OSNSA on Students' Academic Achievement

\section{CONCLUSION}

The purpose of the study was to see if there was a link between students' usage of OSNSA and their academic accomplishment. According to the findings, most respondents have mobile phones with internet access and are familiar with OSNSA. The study found that students' usage of OSNSA had a detrimental impact on their academic success and a positive association between OSNSA usage and academic accomplishment. There is a detrimental correlation between OSNSA and students' academic achievement, far greater than the benefits gained from using OSNSA. Students get addicted to using OSNSA. This wastes their time and in the prescribed time students are often unable to produce their work. OSNSA also develops students' skills and they could understand more things if they positively use it. Technology has both advantages and disadvantages. It depends on you whether you use it in the right way or a wrong way. Social networking sites are beneficial when you use them at a certain age level. For example, if a person uses social networking sites at a teenage it will be helpful because a person is mature enough to differentiate between right and wrong. Parents should keep check and balance if they provide such technology to children.

\section{LIMITATION AND STUDY FORWARD}

In this study, data was collected from only one university, The Islamia University of Bahawalpur. Keeping in view the importance of this idea, other public and private sector universities from Punjab and other Pakistan provinces should also be included in the other similar study.

\section{ACKNOWLEDGEMENT}

This is a self-supported study conducted by the Department of Educational Training, IUB, and Department of Education, GSCWU Bahawalpur. No funding or grant was received for this study. 


\section{AUTHORS CONTRIBUTION}

First Author conceived of the presented idea and proof outline. The second and third authors took the lead in writing the manuscript with support from the third author. The fourth \& fifth authors contributed to the statistical analysis and interpretation of the results. All authors provided critical feedback, helped shape the research, discussed the results, and contributed to the final version of the manuscript.

\section{REFERENCES}

1. Abdullahi, A. Y., Musa, M. M., \& Yusif, N. D. (2020). The Impact of social media on Academic Performance among Undergraduate Students of Bayero University, Kano. International Journal of Education and Evaluation, 6(1), 43-52.

2. Abrha, A. H. (2019). Assessing the Effects of social media on Academic Performance of Female Students at Raya University, Ethiopia. New Media and Mass Communication 81, 15-23. https://doi.org/10.7176/NMMC

3. Asha, N. (2017). Role conflict as related to perceived need satisfaction. The Indian Journal of Social Work, 41(1), 29-33.

4. Bettmann, J. E., Anstadt, G., Casselman, B., \& Ganesh, K. (2020). Young Adult Depression and Anxiety Linked to Social Media Use: Assessment and Treatment. Clinical Social Work Journal. https://doi.org/10.10 07/s10615-020-00752-1

5. Busalim, A. H., Masrom, M., \& Zakaria, W. N. B. W. (2019). The impact of Facebook addiction and selfesteem on students' academic performance: A multi-group analysis. Computers \& Education, 142, 103651. https://doi.org/10.1016/j.compedu.2019.103651

6. Cicekci, M. A., \& Sadik, F. (2019). Teachers' and Students' Opinions about Students' Attention Problems during the Lesson. Journal of Education and Learning, 8(6), 15-30. https://doi.org/10.5539/jel.v8n6p15

7. Celestine, A. U., \& Nonyelum, O. F. (2018). Impact of social media on students' academic performance. International Journal of Scientific \& Engineering Research, 9(3), 1454-1462.

8. Connelly, L., \& Osborne, N. (2017). Exploring risk, privacy and the impact of social media usage with undergraduates. Paper presented at the Proceedings of the European Conference on social media.

9. Cox, D., \& McLeod, S. (2014). Social media strategies for school principals. NASSP Bulletin, 98(1), 5-25. https://doi.org/10.1177/0192636513510596

10. Dahlstrom, E., Grunwald, P., de Boor, T., \& Vockley, M. (2011). ECAR National study of students and information technology in higher education, 2011. EDUCUASE Center for Applied Research. Retrieved from http://net.educause.edu/ir/library/pdf/ERS1103/ERS1103W.pdf

11. David, O. N., Helou, A. M., \& Rahim, N. Z. A. (2012). Model of perceived influence of academic performance using social networking. International Journal of Computers \& Technology, 2(2a), 24-29. https://doi.org/1 $\underline{0.24297 / i j c t . v 2 i 1.2612}$

12. de Calheiros Velozo, J., \& Stauder, J. E. (2018). Exploring social media use as a composite construct to understand its relation to mental health: A pilot study on adolescents. Children and Youth Services Review, 91, 398-402. https://doi.org/10.1016/j.childyouth.2018.06.039

13. Di Minin, E., Fink, C., Hausmann, A., Kremer, J., \& Kulkarni, R. (2021). How to address data privacy concerns when using social media data in conservation science. Conservation Biology, 35(2), 437-446. https://doi.org/1 $0.1111 /$ cobi. 13708

14. Emanuela, T. A. (2018). The impact of social media on recruitment. Ovidius" University Annals, Economic Sciences Series, XVIII, 537-541.

15. Gierdowski, D. C. (2019). ECAR Study of Undergraduate Students and Information Technology, Louisville, CO: ECAR. https://library.educause.edu/resources/2019/10/2019-study-of-undergraduate-students-and-infor mati o n-t echnology

16. Grønmo, S. (2019). Social research methods: Qualitative, quantitative and mixed methods approaches: Sage.

17. Gupta, D., \& Chitkara, S. (2018). Effect of time management on academic performance of management students. Global Journal on Recent Advancement in Business Forecasting and Marketing Intelligence, 2(1), 114.

18. Han, R., \& Xu, J. (2020). A Comparative study of the role of interpersonal communication, traditional media and social media in pro-environmental behavior: A China-based study. International journal of environmental research and public health, 17(6), 1883. https://doi.org/10.3390/ijerph17061883

19. Indurthi, V., Syed, B., Gupta, M., \& Varma, V. (2020). Predicting Clickbait Strength in Online social media. Paper presented at the Proceedings of the 28th International Conference on Computational Linguistics, Coling, Barcelona, Spain (Online). https://doi.org/10.18653/v1/2020.coling-main.425

20. Jena, A. K. (2019). Effects of asynchronous e-mail intervention on learning performance in relation to thinking skills, executive functions and attention benefits of Indian children. The Online Journal of Distance Education and e-Learning, 7(3), 151-168.

21. Karim, S., \& Kandy, M. (2011). Time management skills impact on self-efficacy and academic performance. Journal of American Science, 7(12), 720-726. 
22. Klimova, B. (2019). Impact of mobile learning on students' achievement results. Education Sciences, $9(2), 90$. https://doi.org/10.3390/educsci9020090

23. Kumar Behera, S. M. (2021). Use Of social media For Academic Practices in Higher Education and Its Pros \& Cons: A Review. EPRA International Journal of Multidisciplinary Research (IJMR), 7(5), 436-439 https://doi.org/10.36713/epra2013

24. Laranjo, L., Arguel, A., Neves, A. L., Gallagher, A. M., Kaplan, R., Mortimer, N., . . . Lau, A. Y. (2015). The influence of social networking sites on health behavior change: a systematic review and meta-analysis. Journal of the American Medical Informatics Association, 22(1), 243-256. https://doi.org/10.1136/amiajnl-2014$\underline{002841}$

25. Nasrullah, S., \& Khan, M. S. (2015). The Impact of Time Management on the Students' Academic Achievements. Journal of Literature, Languages and Linguistics, 11, 66-71.

26. Nicholson, O. (2018). The Oxford dictionary of late Antiquity: Oxford University Press. https://doi.org/10.1 093/acref/9780198662778.001.0001

27. Obi, N., Bulus, L., Adamu, G., \& Sala'at, A. (2012). The need for safety consciousness among Youths on social Networking Sites. Journal of Applied Science and management (JASM), 14(1), 29.

28. Onurkan Aliusta, G., \& Özer, B. (2017). Student-centred learning (SCL): roles changed? Teachers and Teaching, 23(4), 422-435. https://doi.org/10.1080/13540602.2016.1205014

29. Paul, J. A., Baker, H. M., \& Cochran, J. D. (2012). Effect of online social networking on student academic performance. Computers in Human Behavior, 28(6), 2117-2127. https://doi.org/10.1016/j.chb.2012.06.016

30. Razali, S. N. A. M., Rusiman, M. S., Gan, W. S., \& Arbin, N. (2018). The Impact of Time Management on Students' Academic Achievement. Journal of Physics: Conference Series, 995, 012042. https://doi.org/1 0.1088/1742-6596/995/1/012042

31. Schroeder, A., Minocha, S., \& Schneider, C. (2010). The strengths, weaknesses, opportunities and threats of using social software in higher and further education teaching and learning. Journal of computer assisted learning, 26(3), 159-174. https://doi.org/10.1598/JAAL.52.3.7

32. Sobaih, A. E. E., Moustafa, M. A., Ghandforoush, P., \& Khan, M. (2016). To use or not to use? Social media in higher education in developing countries. Computers in Human Behavior, 58, 296-305. https://doi.org/10.10 16/j.chb.2016.01.002

33. Talaue, G. M., AlSaad, A., AlRushaidan, N., AlHugail, A., \& AlFahhad, S. (2018). The impact of social media on academic performance of selected college students. International Journal of Advanced Information Technology, 8(4/5), 27-35. https://doi.org/10.5121/ijait.2018.8503

34. Tayo, S. S., Adebola, S. T., \& Yahya, D. O. (2019). Social Media: Usage and Influence on Undergraduate Studies in Nigerian Universities. International Journal of Education and Development using Information and Communication Technology, 15(3), 53-62.

35. Tess, P. A. (2013). The role of social media in higher education classes (real and virtual)-A literature review. Computers in Human Behavior, 29(5), A60-A68. https://doi.org/10.1016/j.chb.2012.12.032

36. Rodríguez-Longarela, I. (2020). Measuring Engagement and Attention by Means of Electronic Response Systems. SSRN Electronic Journal. https://doi.org/10.2139/ssrn.3632766 